DOI: https://doi.org/10.24144/2409-6857.2018.2(52).171-177

УДК 336.76, 330.45: 330.46

Калач Г.М.

\title{
ЦИФРОВА ТРАНСФОРМАЦІЯ ФОНДОВОГО РИНКУ
}

\begin{abstract}
В статті досліджується вплив ичифровізації на процеси трансформації фондового ринку. Проаналізовано основні канали, через які циифровізація якісно змінює фондовий ринок: технологї комунікацї, технології збирання та обробки інформачії, штучний інтелект, біометрія, криптографія, технології розподіленого реєстру, фінансові технології. Визначено основні напрями трансформації суб'єктів, інструментів, облікової та розрахунково-клірингової структури, елементів та бізнес-процесів фондового ринку, щцо реалізуються через зазначені канали.
\end{abstract}

Ключові слова: фондовий ринок, трансформація, цифрровізація, технології розподіленого реєстру, фінансові технології, штучний інтелект, біометрія, криптографія.

Постановка проблеми. Розвитку цифрової економіки приділяється значна увага у сучасному світі, як на корпоративному, так і на офіційному рівні. За даними Єврокомісії, в країнах Євросоюзу, в березні 2017 року реалізовувалось більше тридцяти національних програм та ініціатив 3 питань цифрової економіки.[1] Цифровізацію (діджиталізацію) економіки вважають Четвертою промисловою революцією. Технологічні революції характеризуються довготривалим впливом на всі галузі економіки i суспільного життя, завдяки дифузії та самовдосконаленню базової технології. Оцінки можливого впливу / ефекту цифровізації на окремі галузі і групи галузей світової економіки містяться в доповіді Всесвітнього економічного форуму (WEF). [2]

Цифрова технологічна революція має надзвичайно високу швидкість розповсюдження інновацій, вона може, з одного боку, повністю змінюе не лише повсякденне життя, змінили взаємовідносини між продавцями та споживачами фінансових послуг, але й трансформують саму економічну модель. Цифровізація це пучок інновацій, які є потужним трансформатором для соціально-економічних систем, вона змінює структуру і якість процесів в системі, підвищуючи іiі ефективність. Але трансформація може мати і руйнівні наслідки для ринків, які не здатні адаптуватись до нових технологій. Тому важливо зрозуміти сутність, масштаб і задачі трансформації, що викликані цифровізацією.

Аналіз останніх досліджень i публікацій. Дос- лідженням проблем цифровізації і їі впливу на окремі сфери економіки присвячено

(C) Калач Ганна Миколаївна, к.е.н.,, доцент кафедри економіки підприємства, Національний університет державної фіскальної служби України, м. Ірпінь, тел. 063-561-40-67, e-mail: a.n.kalach@gmail.com вже багато робіт вітчизняних та зарубіжних вчених. Серед зарубіжних праць слід відзначити роботи Д. Тапскотта (Tapscott, 1995), який передбачив зменшення трансакційних витрат під впливом цифрових технологій[3]; Клауса Шваба, який ввів термін «четверта промислова революція», окреслив основні риси нової технологічної цивілізації, іiі позитивні ефекти і небезпеки[4]. Проблемам цифровізації приділяється багато уваги фахівцями Міжнародного валютного фонду [5], грунтовний аналіз напрямів трансформації традиційних галузей в умовах цифровізації проведено російськими вченими [6]. Системне дослідження тенденцій розвитку цифрової економіки проведено в монографії О.С.Ляшенко[7], грунтовне дослідження категорії «цифровізація» проведено в статті С.В.Коляденко[8]. Серед публікацій, які пов'язнані з визначенням впливу цифровізації на трансформацію фінансового ринку варто відзначити статті С.А.Циганова та В.В.Апалькової[9], М.В.Тарасюка, О.О.Кощеєва[10], Н.М.Пантелєєвої[11].

Фондовий ринок, грунтується на використанні інформаційних технологій оскільки операції 3 цінними паперами пов'язані зі збором, зберіганням i обробкою великих масивів інформації. Одночасно, під впливом цифрових інновацій відбувається процес трансформації фондового ринку. Під трансформацією фондового ринку ми розуміємо такий спосіб або форму розвитку системи при якому система в точці біфуркації переходить у якісно новий стан, відбувається зміна ii просторово-часової організації. Сьогодні актуальним є дослідження каналів, напрямів і форм трансформації, що відбуваються на фондовому ринку під впливом цифровізації.

Формулювання цілей статті.. Мета статті полягає у дослідженні напрямів трансформації суб'єктної структури, фінансових інструментів, 
технологій фінансування та управління ризиками фондового ринку, що відбуваються внаслідок цифровізації, а також оцінка стану та можливих наслідків цих процесів в Україні.

Опис основного матеріалу дослідження. На Конференції Організації об'єднаних націй 3 торгівлі та розвитку (UNCTAD) Рауль Кац, директор 3 досліджень бізнес-стратегій в Інституті телеінформації Колумбії надав наступне визначення цифровізації: «В широкому сенсі слова під процесом "цифровізації" розуміється соціально-економічна трансформація, ініційована масовим впровадженням та освоєнням цифрових технологій, тобто технологій створення, оброблення, обміну та передачі інформації».[12] Цифровізація, або «діджиталізація» включає широкий спектр радикальних інновацій, що не лише створюють нові можливості ведення бізнесу та участі у глобальних цифрових платформах, але й якісно трансформують саму економічну модель. До найбільш важливих каналів, через які відбувається трансформація фондового ринку можна віднести технології комунікації, технології збирання та обробки інформації штучний інтелект, біометрію, криптографію, «хмарні» технології, технології розподіленого реєстру, фінансові технології (фінтех) тощо.

Зміна технологій комунікації. Поява та розповсюдження смартфонів та різних мобільних додатків забезпечує технологічну готовність населення до сприйняття інформаційних комп'ютерних технологій (IКТ). ІКТ означають поширення фінансових послуг на широке коло споживачів. Зручні мобільні додатки, які грунтуються на «хмарних» технологіях, призначених для використання на мобільних телефонах та комп'ютерах, дозволяють: отримувати інформацію про стан рахунків, здійснювати та отримувати платежі; купувати товари на різних ринках; користуватись альтернативними видами платежів (електронні та цифрові гаманці, QR(Quick Response)-платежі). Найбільшого поширення через цей канал зазнали такі напрями трансформації фондового ринку: форми розрахунків (інтернет-гаманці, шлюзи прийому онлайн-платежів і швидкі кредити), система управління активами клієнтів (онлайнсистеми з управління активами, наприклад, робоадвайзінг - підбір інвестиційного портфеля за допомогою комп'ютерних алгоритмів), моделі кредитування (краудфандинг, пірінгові системи, балансове кредитування) дозволяе інвесторам напряму брати участь в акціонерному капіталі, не звертаючись до послуг фінансових посередників, таких як інвестиційні фонди. Також трансформується форма та зміст торгових систем. Посередницькі цифрові платформи, які отримали назву маркетплейси з'єднують кредиторів з позичальниками безкоштовно або за невелику плату i таким чином, стають конкурентами фінансовим установам.

\section{Новітні} інформаційно-комунікаційні трансформують не лише інфраструктуру та бізнес-процеси фондового ринку, але й такі категорії як час та простір, які в попередніх економічних системах мали вирішальне значення для процесу ціноутворення цінних паперів. В умовах цифровізації інформація між учасниками фондового ринку миттєво переміщується у глобальному просторі, таким чином, суттево зменшуються трансакційні витрати учасників, пов'язані з пошуком та аналізом інформації. В Україні переваги інформаційно-комунікаційних технологій на фондовому ринку не реалізовані повністю, оскільки стандарти поширення інформації емітентами цінних паперів в Україні не повністю відповідають міжнародним стандартам.

Зміна технологій комунікації якісно трансформувала роль транснаціонального капіталу та вплив іноземних філій на країни перебування. За допомогою портфельного інвестування вони здійснюють необмежений вплив на ринки. Технології не мають кордонів, вони створюють умови для миттєвого переміщення капіталу в ті юрисдикції, які є менш регульованими. Таким чином, у глобальній цифровій економіці транснаціональний капітал став практично непідконтрольним фінансовим інститутам.

Зміна технологій збирання та обробки інформації. Big Data (BD) є вільним терміном для позначення великих обсягів неструктурованих (наприклад, електронних листів, інтернеттрафіку) та структурованих (наприклад, баз даних) даних, аналіз яких неможливий за допомогою традиційних аналітичних інструментів. Включаються також дані, зібрані через такі мережі, як Інтернет або корпоративні інтранети, та інші дані, які організації створюють та зберігають під час звичайного ведення бізнесу. Аналіз великих даних зосереджується, наприклад, на виявленні шаблонів, кореляцій та тенденцій в даних або налаштуваннях кліснтів, може базуватися на машинному навчанні або інших технологіях[13,с1196] Основними напрямами трансформації, що реалізуються через цей канал $€:$ нові фінансові інструменти (складні опціони та багаторівнева сек'юритизація), механізми управління ризиком (розширені можливості обробки великих масивів інформації дозволили передавати ризик від кредитора до покупця похідних цінних паперів). Big Data допомагає 
уникати більшості помилок при прийнятті рішень, оскільки стало можливим короткострокове прогнозування в режимі реального часу («нау-кастинг»). Фахівці 3 управління ризиками можуть за допомогою систем бізнес-аналітики (Business Intelligence (BI)) проаналізувати багаточисельні і складні взаємозв'язки між суб'єктами ринку і оцінити імовірність системного ризику.

Цікавим додатком до кількісного аналізу даних $є$ інтелектуальний аналіз текстів, він вже використовується для ранжирування компаній за ступенем надійності при аналізі фінансових звітів (форма 10-K), що компанії надають в Комісію 3 цінних паперів i бірж США. За допомогою цифрових додатків фахівці довели, що існує взаємозв'язок між складністю мови фінансового звіту i низькими доходами компанії. Інтелектуальний аналіз тисяч новин здійснюють хеджеві фонди, виявляючи значущі для трейдингу зміни в кон'юнктурі ринку. Подібний аналіз був би корисний і регуляторам.

Фінансово-математичні алгоритми, що створені для обробки великих обсягів інформації та миттєвого прийняття рішень можуть в десятки разів підвищити ефективність прийняття рішень, але можуть бути і джерелом нестабільності. Чим більше учасників одночасно керуються ними при прийнятті рішень, тим вище імовірність того, що всі будуть діяти однаково, збільшуючи амплітуду коливання цін.

Договірні відносини. Фінансові установи використовують цифрові системи бізнес-аналізу (BI) для дослідження контрагентів, кредитних портфелів, активності контрагентів, аналізу депозитних портфелів 3 кредитними, в різних зрізах. ВI системи доповнюються предикативною аналітикою даних 3 різних джерел, зібраних в реальному часі. Таким чином, штучний інтелект у поєднанні з різким розширенням даних дозволяє автоматизувати продаж активів за допомогою так званих «інтелектуальних контрактів». Інтелектуальний контракт - це контракт, що може самостійно виконуватися, коли виконуються певні визначені умови, їх розповсюдженню сприяє розвиток таких цифрових інновацій як криптографія та біометрія. Таким чином, основним напрямком трансформації фондового ринку через цей канал $є$ зміна розрахунковоклірингової системи, з часом роль реєстраторів, депозитаріїв та розрахунков-клірингових банків будуть виконувати фінтах компанії.

Криптографія та біометрія. Криптографія дозволяє шифрувати інформацію для переведення iii у безпечний формат, створювати електронні маркери, які замінюють конфіденційні персональні дані клієнта унікальною послідовністю цифр. Маркери можуть передаватися на будь-яку відстань, тобто мають трансграничний характер. Маркери дозволяють на порядок зменшити транзакційні витрати при проведенні трансграничних розрахунків. Біометрія стосується віддаленої ідентифікації особи шляхом цифрового охоплення та зберігання унікальних характеристик окремих осіб, таких як клієнти (наприклад, відбитки пальців, радужки, голос, обличчя) здебільшого 3 метою підвищення безпеки (i зручності) фінансових операцій. В Україні поки тільки оператор «Київстар» оголосив про запуск послуги віддаленої ідентифікації MobileID, яка дозволяє телефону визначати клієнта i використовувати його цифровий підпис для отримання електронних послуг.

Зворотній бік криптографії та біометрії полягає у надмірній концентрації інформації і будь-яке порушення в системі, або кібератака будуть означати настання системного ризику.

Блокчейн технології. Технологія розподіленого реєстру (блокчейн) дозволяє зберігати інформацію про трансакції в окремих, не пов'язаних між собою блоках. Кожен блок містить інформацію по попередньому блоці, таким чином, інформація багаторазово копіюється i жоден учасник мережі не може іi змінити. При укладанні угоди операція перевіряється в мережі і знову повертається в мережу 3 інформацією про учасників угоди. Транзакція вважається завершеною і достовірною (підтвердженою), коли перевірені іiі формат i підписи, і коли сама транзакція об'єднана в групу 3 декількома іншими і записана в блок. Технологія блокчейн трансформує облікову і розрахункову структури фондового ринку, при переведенні реєстрів власників цінних паперів в цифровий формат стають непотрібними послуги реєстраторів. Крім того, зміняться функції та технологія роботи фондових бірж. За інформацією Європейської економічної комісії, першою фондовою біржею, що вирішила використовувати блокчейн технології для контролю за виконанням договорів $\epsilon$ Австралийска біржа цінних паперів (ASX), також відомо, що експериментують 3 використанням цієї технологіi такі біржі як Американська фондова біржа Nasdaq, лондонська фондова біржа (LSE) та Токійська фондова біржа (JPX).

Трансформація розрахункові та облікові системи цінних паперів, з одного боку, підвищує безпеку трансакцій, а 3 іншого - $\epsilon$ елементом каналу перенесення порушень у функціонуванні ринків та фінансових організацій. По мірі відходу від врівноваженої структури розрахунків та обліку до структури, у якій наявні глобальні 
центри грошових розрахунків, проблема трансмісії порушень розрахунковою інфраструктурою втрачає гостроту всередині держави, водночас збільшуючись при транскордонних розрахунках.

Штучний інтелект (artificial intelligence, AI). Нові алгоритми, що імітують роботу людського мозку дозволяють використовувати цифрові нейронні мережі для виявлення закономірностей шляхом переробки величезних масивів даних. Фондовий та фінансовий ринки саме і $є$ місцем для впровадження штучного інтелекту, адже оперують величезними об'сягами даних, що постійно генеруються і потребують управління. Завдяки штучному інтелекту стає можливим індивідуальне консультування 3 питань управління фінансами, автоматизація та роботизація процесу спілкування 3 клієнтами. Наприклад, американська компанія Narrative Science, що спеціалізується на розробці технологій штучного інтелекту, розробила платформу штучного інтелекту Quill, яка перетворює дані на зв'язний текст, цією платформою вже користується Forbes для автоматичного складання звітів.

ФінТех (фінансові технологіï). Цей термін використовується для позначення не лише фінансових технологій як продукту, але й для розробників продуктів та компаній-операторів альтернативних платіжних та розрахункових систем. Більшість ФінТехів починали свою діяльність як технологічні компанії постачальники цифрових продуктів для фінансового сектору, але нині вони самі стають учасниками фінансового ринку i суттево трансформують його. Екосистема ФінТех поєднує всіх учасників фінансового ринку: ФінТех-стартапи, регуляторів, банки, міжнародні платіжні системи, асоціації банкірів та фінансистів, інкубаторів, акселераторів, постачальників.[15] ФінТех компанії сприяють поширенню фінансових послуг у найвіддаленіших населених пунктах, де не має банківських відділень, або інших фінансових установ, здебільшого їх послуги мають трансакційну природу і пов'язані 3 обробкою великих обсягів інформації. Переважно сфера інтересів ФінТех компаній зосереджена на переказах, платежах (53\%) і кредитуванні (25\%), обробці інформації, проте вже сьогодні вони надають також послуги з управління активами, брокерські послуги, інвестування, страхування, кредитування тощо. [16]

Підсумовуючи проведений аналіз, спробуємо узагальнити отримані результати (таб.1).

Напрями трансформації елементів фондового ринку в умовах цифровізації*

\begin{tabular}{|c|c|c|}
\hline $\begin{array}{l}\text { Основні складові структури } \\
\text { фондового ринку }\end{array}$ & Елементи «класичної» моделі & Елементи «цифрової» моделі \\
\hline Фінансові посередники & $\begin{array}{l}\text { Брокери } \\
\text { Дилери }\end{array}$ & $\begin{array}{l}\text { ФінТех } \\
\text { Високочастотний трейдинг } \\
\text { Хеджеві фонди }\end{array}$ \\
\hline $\begin{array}{l}\text { Організації, що забезпечують } \\
\text { укладання угод }\end{array}$ & $\begin{array}{l}\text { Фондова біржа } \\
\text { Позабіржові торгові системи }\end{array}$ & $\begin{array}{l}\text { ФінТех } \\
\text { Блокчейн }\end{array}$ \\
\hline $\begin{array}{l}\text { Організації, що забезпечують } \\
\text { виконання угод }\end{array}$ & $\begin{array}{l}\text { Реєстратори } \\
\text { Депозитарії } \\
\text { Розрахунково-клірингові організації }\end{array}$ & $\begin{array}{l}\text { ФінТех } \\
\text { Платіжні сервіси IT платформ }\end{array}$ \\
\hline Фінансові інструменти & $\begin{array}{l}\text { Пайові цінні папери } \\
\text { Боргові цінні папери } \\
\text { Похідні цінна папери }\end{array}$ & $\begin{array}{l}\text { Складні опціони } \\
\text { Багаторівнева сек’юритизація } \\
\text { Біткоїн деривативи } \\
\text { Цифрові токени }\end{array}$ \\
\hline Фінансові послуги & $\begin{array}{l}\text { Інвестування } \\
\text { Аналітика }\end{array}$ & $\begin{array}{l}\text { Інвестування, брокерські послуги } \\
\text { через ФінТех } \\
\text { Діджитал кредитування } \\
\text { Краудфандінг на основі акцій } \\
\text { Роботизоване управління активами }\end{array}$ \\
\hline
\end{tabular}

*Складено автором на основі $[7,9,10,11,14]$

Механізм трансформації «класичної» моделі в «цифрову» закладено Європейською платіжною директивою PSD2 (Payment Services Directive revised), яка вступила в дію 13 січня 2016 року. Ця директива передбачає заміну існуючої фінансової системи на «цифрову», 3 цією метою вводиться новий тип фінансових інститутів - фінансові посередники (це $\mathrm{i} \in$ фінансово технологічні компанії, які ми розглядали в цій статті). Діяльність фінансових посередників нового типу буде здійснюватись на підставі двох типів ліцензій. Перший вид ліцензії (payment initiation 
service provider) передбачає здійснення посередницьких послуг 3 надання інтерфейсів по здійсненню платежів, при цьому система договірних відносин замінюється законодавчо затвердженими правилами взаємодії між користувачем та провайдером послуг. Таким чином, користувачі отримають надзвичайно зручний сервіс, який дозволить здійснювати платежі без звернення в банки, отже роль банків у зв'язку 3 цією директивою також суттєво змінюється, цей напрямок трансформації повинен бути предметом окремого дослідження. Другий вид ліцензій (account information service providers) надає право фінансовому посереднику - власнику ліцензії право на накопичення, консолідацію і передавання фінансової інформації (таку інформацію консолідують найбільші технологічні компанії такі як Apple, Microsoft). У відповідності до PSD2 в ЄС буде створено загальноєвропейський реєстр платіжних інститутів та їх агентів, цей реєстр включатиме всі платіжні системи, що підключені до DNS серверів (Domain name system), це кореневі DNS сервера, в світі їх всього 13, отже технічно це зробити не складно. [17]

Висновки i перспективи подальших досліджень. Таким чином, діджиталізація суттєво трансформує суб'єктну, облікову, інструментальну та розрахунково-клірингову структури фондового ринку. На теперішньому етапі між суб'єктами традиційної фінансової системи та новими інституційними учасниками (ФінТехами) здебільшого встановилися партнерські відносини, але в недалекому майбутньому ФінТех компанії можуть повністю замінити посередників на фондовому ринку, за рахунок таких переваг як мобільність, зручність, швидкість, низька вартість обслуговування, візуалізація. У деяких європейських країнах вже відбувся поділ: банки займаються фондуванням, а транзакційними сервісами - ФінТех. Згодом, в разі лібералізації законодавства, ФінТехи можуть скласти серйозну конкуренцію як банкам, так i небанківським фінансовим установам за рахунок надання різноманітних, більш дешевих i доступних послуг.

Треба враховувати зворотній бік цифровізації: складність мереж, інтенсивність капіталу та інформації, що рухаються цими мережами наражає глобальну фінансову систему на системні ризики. Зростаюча складність посилює фінансову нестабільність, оскільки інститути, що повинні регулювати діяльність глобальних систем нездатні простежити причинонаслідкові зв'язки і передбачити можливі збої в роботі глобальних систем. Зараз цифрова економіка знаходиться на тому етапі розвитку, коли стандарти та норми регулювання лише починають розроблятися та затверджуватися. Затримка в прийнятті регуляторних норм призведе до уповільнення розвитку цифровізації та становлення інноваційної бізнес-моделі, залишить країну на узбіччі світових трендів, тому потребують подальшого дослідження основні тренди цифровізації, напрями становлення регуляторних норм, напрями розвитку мобільних додатків. Для України актуальним є питання адаптації до Європейської платіжної директиви PSD2 (Payment Services Directive revised) що закладає основу та принципи створення нової фінансової системи, міжнародні стандарти регулювання цифровізації та захист прав інвесторів і споживачів. Ще важливішою задачею $\epsilon$ створення правової бази для функціонування фінансово технологічних компаній в Україні, для того, щоб вони вчасно адаптувалися до виконання функцій, передбачених директивою PSD2.

\section{ПЕРЕЛІК ВИКОРИСТАНИХ ДЖЕРЕЛ}

1. Coordination of European, national \& regional initiatives. Materials of the European Commission. (2016). Retrieved from https://ec.europa.eu/digital-single-market/en/cordination-european-national-regional-initiatives

2. World Economic Forum, Digital Transformation Initiative. Unlocking $\$ 100$ Trillion for Business and Society from Digital Transformation. Executive Summary, January 2017 (In collaboration with Accenture). (2017). Retrieved from https://www.weforum.org/whitepapers/digital-transformation-initiative

3. Тапскотт Д. Электронно-цифровое общество: плюсы и минусы эпохи сетевого интеллекта. / Ден Тапскотт; пер. с анг. Игоря Дубинского; под ред. Сергея Писарева - М.: Релф бук, 1999. - 432 с.

4. Шваб К. Четвертая промышленная революция. / Клаус Шваб; перевод с английского. - М.: Издательство «Э», 2017. $-208 \mathrm{c}$.

5. Гриффоли Т.М. Ставка на перемены./ Т.М. Гриффоли //Финансы и развитие: електрон.изд. - 2017. сентябрь. - Режим доступу: http://www.imf.org/external/russian/pubs /ft/fandd/2017/09/index.htm.

6. Цифровая економіка: глобальные тренди и практика росийского бизнеса. Доклад Института менеджмента инноваций. Режим доступу: https://imi.hse.ru/data/pdf. 
7. Ляшенко В.І., Вишневський О.С. Цифрова модернізація економіки України як можливість проривного розвитку: монографія. / В.І. Ляшенко, О.С. Вишневський - Київ: НАН України, Ін-т економіки пром-сті, 2018. $252 \mathrm{c}$.

8. Коляденко С.В. Цифрова економіка: передумови та етапи становлення в Україні і у світі./ С.В. Коляденко// ЕКОНОМІКА. ФІНАНСИ. МЕНЕДЖМЕНТ: актуальні питання науки і практики. - 2016 - № 6 - c.105-111.

9. Циганов С. А., Апалькова В. В. Розвиток інноваційної інфраструктури глобального ринку платіжних послуг./ С. А. Циганов, В. В. Апалькова // «Фінанси України». - 2016 - №2. - с.100-110.

10. Тарасюк М.В., Кощеєв О.О. Інновації в глобальній цифровій фінансовій сфері: оцінка трансформацій. / М.В.Тарасюк, О.О. Кощеєв // «Актуальні проблеми міжнародних відносин.» - 2017 - Випуск 131.- с. 94-110.

11. Пантелєєва Н. М. Фінансові інновації в умовах цифровізації економіки: тенденції, виклики та загрози./ Н. М. Пантелєєва // «Приазовський економічний вісник.»- 2017p. - Випуск 3 (03).- с. 69-73.

12. Katz Raúl L. The Transformative Economic Impact of Digital Technology. / Raúl L.Katz // THE UNITED NATIONS COMMISSION ON SCIENCE AND TECHNOLOGY FOR DEVELOPMENT. Retrieved from http://unctad.org/meetings/en/Presentation/ecn162015p09_Katz_en.pdf.

13. Поченчук Г.М. Фінансові технології: розвиток і регулювання./ Г.М. Поченчук // «Економіка i суспільство.»- 2017 р. - Випуск 13.- с. 1193-2000.

14. Обзор цифровой повестки в мире. Дайджест Европейской экономической комиссии. - Декабрь 2017г. Режим доступу:

http://www.eurasiancommission.org/ru/act/dmi/workgroup/Documents/digest/\%D0\%94\%D0\%B0\%D0\%B9\%D0\%B4 $\%$ D0\%B6\%D0\%B5\%D1\%81\%D1\%82\%2015.12.2017.pdf

15. Фінтех в Україні: тенденції, огляд ринку та каталог. Проект USAID «Трансформація фінансового сектору» - Режим доступу: http://data.unit.city/fintech/fgt34ko67mok/fintech_in_Ukraine_2018_ua.pdf

16. Проект A.16. «FinTech Market Development». Комплексна програма розвитку фінансового сектору до 2020 року. VI Ukrainian Banking Forum. - Київ. - 20 жовтня 2017 р. - Режим доступу: https://www.slideshare.net/cisbankers/project-a16-fintech-market-development.

17. Платежная директива Евросоюза PSD2. Комплексній аналіз и мери противодействия. - Режим доступу: http://www.ecommerce-payments.com/psd2-revised-payment-services-directive.html

\section{REFERENCES}

1. Coordination of European, national \& regional initiatives. Materials of the European Commission. (2016). Retrieved from https://ec.europa.eu/digital-single-market/en/cordination-european-national-regional-initiatives

2. World Economic Forum, Digital Transformation Initiative. Unlocking \$100 Trillion for Business and Society from Digital Transformation. Executive Summary, January 2017 (In collaboration with Accenture). (2017). Retrieved from https://www.weforum.org/whitepapers/digital-transformation-initiative

3. Tapskott D. (1999). Elektronno - cifrovoe obschestvo: plyusy i minusy epohi setevogo intellekta. [Electronic-digital society: the pros and cons of the age of network intelligence.] - Moscow: Relf beech. [in Russian]

4. Shvab K. (2017). Chetvertaya promyshlennaya revolyuciya. [The Fourth Industrial Revolution.] - M .: Publishing House "E". [in Russian]

5. Griffoli T.M. (2017). Stavka na peremeny. [Bet for change.] Retrieved from http://www.imf.org/external/russian/pubs /ft/fandd/2017/09/index.htm

6. Cifrovaya ekonomika: global'nye trendi i praktika rosiyskogo biznesa. Doklad Instituta menedzhmenta innovaciy. (2017). [Digital economy: global trends and the practice of Russian business. Report of the Institute for Innovation Management.] Retrieved from https://imi.hse.ru/data/pdf.

7. Lyashenko V.I., Vy`shnevs`ky`j O.S. (2018). Cy`frova modernizaciya ekonomiky`Ukrayiny`yak mozhly`vist` prory`vnogo rozvy`tku: monografiya. [Digital modernization of the Ukrainian economy as an opportunity for breakthrough development: a monograph.] - Kyiv: NAS of Ukraine, Institute of Industrial Economics. [in Ukrainian].

8. Kolyadenko S.V. (2016). Cy`frova ekonomika: peredumovy` ta etapy` stanovlennya v Ukrayini i u sviti. [Digital economy: preconditions and stages of formation in Ukraine and in the world.] Economy. Finances. Management: topical issues of science and practice, 6, 105-111. [in Ukrainian].

9. Cy`ganov C. A., Apal`kova V. V. (2016). Rozvy`tok innovacijnoyi infrastruktury`global`nogo ry`nku platizhny`x poslug. [Development of innovation infrastructure of the global payment services market.] Finance of Ukraine, 2, $100-$ 110. [in Ukrainian].

10. Tarasyuk M.V., Koshheyev O.O. (2017) Innovaciyi v global`nij cy`frovij finansovij sferi: ocinka transformacij. [Innovations in the Global Digital Financial Sector: Assessing Transformations.] Actual problems of international relations, 131, 94-110. [in Ukrainian].

11. Pantelyeyeva N. M. (2017). Finansovi innovaciyi v umovax cy`frovizaciyi ekonomiky`: tendenciyi, vy`kly`ky` ta zagrozy. [Financial innovations in the conditions of digitalization of the economy: trends, challenges and threats.] Azov Economic Bulletin, 3 (03), 69 - 73. [in Ukrainian].

12. Katz Raúl L. (2015). The Transformative Economic Impact of Digital Technology. THE UNITED NATIONS COMMISSION ON SCIENCE AND TECHNOLOGY FOR DEVELOPMENT. (Electronic resource). Retrieved from http://unctad.org/meetings/en/Presentation/ecn162015p09_Katz_en.pdf. 
13. Pochenchuk G.M. (2017). Finansovi texnologiyi: rozvy`tok i regulyuvannya. [Financial technologies: development and regulation.] Economics and Society, 13, 1193-2000. [in Ukrainian].

14. Obzor cifrovoy povestki v mire. Daydzhest Evropeyskoy ekonomicheskoy komiscii. (2017) [Review of the Digital Agenda in the World. Digest of the European Economic Commission.] Retrieved from http://www.eurasiancommission.org/ru/act/dmi/workgroup/Documents/digest/\%D0\%94\%D0\%B0\%D0\%B9\%D0\%B4 $\%$ D0\%B6\%D0\%B5\%D1\%81\%D1\%82\%2015.12.2017.pdf [in Russian]

15. Fintex v Ukrayini: tendenciyi, oglyad ry`nku ta katalog.: Proekt USAID «Transformaciya finansovogo sektoru». ( 2018). [Finteh in Ukraine: trends, market overview and catalog. : USAID Transformation of the Financial Sector Project.] Retrieved from http://data.unit.city/fintech/fgt34ko67mok/fintech_in_Ukraine_2018_ua.pdf

16. Proekt A.16. «FinTech Market Development».: Kompleksna programa rozvy`tku finansovogo sektoru do 2020 roku. (2017). [ Project A.16. FinTech Market Development. : Comprehensive program of financial sector development till 2020.] Retrieved from https://www.slideshare.net/cisbankers/project-a16-fintech-market-development.

17. Platezhnaya direktiva Evrosoyuza PSD2. Kompleksnij analiz i meri protivodejstviya. (2018). [EU Payment Transfer Directive PSD2. Comprehensive analisis and measures of resistance.] Retrieved from http://www.ecommercepayments.com/psd2-revised-payment-services-directive.html

Одержано 14.09.2018 p. 